\title{
Gambaran Indeks Massa Tubuh dan Densitas Massa Tulang sebagai Faktor Risiko Osteoporosis pada Wanita
}

\section{The Profile of Body Mass Index and Bone Mass Density Scan as Osteoporosis Risk Factor among Female}

\author{
Humaryanto, Ahmad Syauqy
}

Program Studi Kedokteran Fakultas Kedokteran dan Ilmu Kesehatan Universitas Jambi Jambi

\begin{abstract}
ABSTRAK
Osteoporosis merupakan suatu kondisi kelainan yang ditandai penurunan densitas massa tulang dengan risiko mikrofraktur, terutama fraktur pinggul. Faktor risiko osteoporosis diantaranya adalah indeks massa tubuh (IMT) yang rendah. Penelitian ini bertujuan untuk membuktikan hubungan antara IMT dan status densitas massa tulang (DMT) pada 347 orang wanita dewasa di kota Jambi pada tahun 2017 melalui pemeriksaan Ultrasound bone densitometry. Penelitian dilakukan dengan rancangan penelitian observasional analitik dengan pendekatan cross-sectional. Sampel penelitian terbanyak pada kelompok IMT normal 37,2\% dengan hasil DMT pada kelompok osteoporosis 48,7\%. Hasil penelitian menunjukkan bahwa pada kelompok obesitas memiliki nilai DMT osteoporosis yang lebih banyak dibandingkan kelompok lainnya namun tidak ada hubungan yang bermakna secara statistik antara IMT dengan DMT $(p=0,132)$.
\end{abstract}

Kata Kunci: Indeks Massa Tubuh, Densitas Massa Tulang, osteoporosis

\section{ABSTRACT}

Osteoporosis is an abnormal condition characterized by a decrease in bone mass density with the risk of microfracture, especially hip fractures. The osteoporosis risk factors are including low body mass index (BMI). This study aimed at proving the relationship between body mass index and bone mass density (BMD) among 347 adult females who underwent ultrasound bone densitometry (QUS) scanning in Jambi in 2017. The study was conducted using an observational analytic study design with a cross-sectional approach. The majority of the samples was in the normal BMI group (37.2\%), with BMD on osteoporosis (48.7\%). The results showed that the obese group had more osteoporotic BMD values than the other groups, but there was no statistically significant relationship between $B M I$ and $B M D(p=0.132)$.

Keywords: Bone Mass Density, Body Mass Index, Osteoporosis

Korespondensi: Humaryanto. Program Studi Kedokteran Fakultas Kedokteran dan Ilmu Kesehatan Universitas Jambi, Jl. Letjen Suprapto No.33 Telanaipura Jambi Tel. (0741)60246Email: humaryanto_fkik@unja.ac.id

DOI: http://dx.doi.org/10.21776/ub.jkb.2019.030.03.10 


\section{PENDAHULUAN}

Osteoporosis adalah kelainan yang ditandai dengan penurunan densitas massa tulang serta gangguan arsitektur tulang normal yang mempengaruhi kekuatan tulang sehingga mengakibatkan peningkatan risiko fraktur. Penyakit osteoporosis umumnya tanpa disertai gejala namun terjadi secara progresif selama bertahuntahun. Pada tahap lanjut osteoporosis mengakibatkan patah tulang (fraktur patologis), punggung yang semakin membungkuk (kifosis), hilangnya tinggi badan, atau nyeri punggung. Berkurangnya kepadatan tulang atau densitas masa tulang (DMT) akan mengakibatkan rusaknya struktur tulang belakang dan kelainan bentuk tulang yang menyebabkan nyeri punggung menahun (1). World Health Organization (WHO) melaporkan pada tahun 1990 angka kejadian fraktur akibat osteoporosis di dunia berada di angka 1,7 juta orang dan diprediksi akan meningkat terus sehingga diperkirakan pada tahun 2050 mencapai angka 6,3 juta, dengan 71\% diantaranya akan terjadi di negara berkembang $(2,3)$. Tercatat bahwa terdapat kurang lebih 200 juta pasien di seluruh dunia menderita osteoporosis yang merupakan peringkat kedua setelah penyakit jantung kardiovaskuler.

Sebesar $50 \%$ kejadian fraktur tulang karena osteoporosis di dunia terjadi di Asia, dan Indonesia merupakan negara dengan prevalensi osteoporosis terbesar kedua setelah China. Dibandingkan orang di negara-negara Afrika, maka densitas tulang orang Eropa dan Asia lebih rendah sehingga mempunyai risiko lebih tinggi terjadi osteoporosis (4). Meskipun osteoporosis dapat menyerang laki-laki maupun perempuan tetapi data Kemenkes RI (2015) menunjukkan kejadian osteoporosis lebih mencolok terjadi pada perempuan yang berkaitan dengan penurunan fungsi hormon esterogen yang progresif (5). International Osteoporosis Foundatioan (IOF) melaporkan bahwa 1 dari 4 perempuan berusia 50-80 tahun berisiko terkena osteoporosis empat kali lebih tinggi dibandingkan pria (4). Menurunnya fungsi ovarium dan pola hidup yang kurang baik mengakibatkan prevalensi osteoporosis pada perempuan mencapai $36 \%$, sedangkan pria $27 \%$ (5). Proses penurunan DMT dalam massa absolut tulang tergantung pada bagian tulang, dan berlangsung selama dewasa muda, kemudian cepat pada wanita menopause dan berlanjut secara progresif pada wanita pasca menopause atau pria usia 50 tahun atau lebih (6-8).

Disamping faktor risiko usia dan jenis kelamin, obesitas juga berhubungan dengan osteoporosis. Saat ini masih terdapat kontroversi hubungan antara obesitas yang diukur dengan indeks masa tubuh (IMT) dan DMT. Pada orang kurus dengan nilai IMT<18,5 memiliki risiko osteoporosis tujuh kali dibandingkan dengan orang normal atau obesitas (IMT $\geq 18,5)$. Kondisi ini dimungkinkan karena rendahnya IMT berhubungan dengan rendahnya pencapaian massa tulang puncak dan tingginya massa tulang yang hilang (9). Hal ini serupa dengan penelitian Fawzy et al., yang menyatakan bahwa rendahnya indeks massa tubuh merupakan faktor risiko terjadinya osteoporosis (10). Penelitian Putra melaporkan bahwa pada perempuan usia 30-40 tahun tidak ditemui hubungan yang bermakna pada IMT dan DMT, demikian Robbins et al., menyatakan bahwa untuk DMT, maka IMT bukanlah prediktor yang baik (9). Kesenjangan ini mendorong peneliti untuk mengetahui apakah ada hubungan yang signifikan antara indeks masa tubuh dengan hasil pemeriksaan DMT sebagai metode screening osteoporosis disamping masih terbatasnya kajian di Kota Jambi terkait faktor risiko osteoporosis.

\section{METODE}

Penelitian ini menggunakan metode cross sectional untuk melihat hubungan antara indeks massa tubuh (IMT) dan densitas massa tulang (DMT). Sampel pada penelitian diambil dengan cara consecutive sampling pada populasi target yaitu pasien wanita di kota Jambi yang berobat ke rumah sakit Arafah, Rumah Sakit Kambang dan Klinik Simpang Jawo kota Jambi periode Januari-April 2017. Penentuan jumlah minimal sampel pada penelitian ini menggunakan rumus estimasi proporsi suatu populas dengan $p=0,5$ dan $d=0,1$ sehingga diperoleh minimal jumlah sampel 96 dengan estimasi bias 10\% diperlukan jumlah sampel minimal 106 pasien. Dalam pelaksanaan penelitian sebanyak 347 pasien bersedia berpartisipasi sebagai subjek penelitian

Pengumpulan data dilakukan melalui wawancara (karakteristik responden) dan pengukuran langung. Nilai indeks IMT diperoleh dari pengukuran tinggi badan dan berat badan dan dikelompokkan berdasarkan standar WHO menurut kelompok Asia Pasifik. Terdapat berbagai cara pemeriksaan densitas tulang, yaitu foto radiologi tulang dengan absorpsimetri foton tunggal (SPA), absorpsi foton Ganda (DPA), tomografi komputer kuantitatif (CT SCAN) DPA dengan energi sinar $X$ ganda (DEXA). Adapun pemeriksaan menggunakan ultrasound digunakan sebagai upaya penapisan awal, sedang DEXA direkomendasi oleh WHO sebagai standar emas untuk pemeriksaan kepadatan tulang $(10,11)$. Nilai DMT diperoleh dengan pemeriksaan pada tumit (tulang kalkaneus) menggunakan alat ultrasound bone densitometry (Quantitative Ultrasound Bone Densitometry) dengan pengelompokan berdasarkan kriteria WHO. Pengukuran DMT dilakukan dengan pengukuran T-score dan Z-score. T-score yaitu angka skor nilai deviasi antara kepadatan tulang pasien dengan kepadatan tulang rata-rata pada populasi orang normal dengan jenis kelamin sama, sedangkan Z-score adalah ukuran standar deviasi nilai kepadatan tulang yang diharapkan pada pasien sesuai usia dan jenis kelamin sama. Secara deskriptif data kategorik disajikan dengan jumlah/frekuensi dan proporsi sedangkan data numerik disajikan dengan rerata, median, standar deviasi dan range. Analisis hubungan dilakukan dengan uji beda proporsi (Chi-Square) dengan nilai kemaknaan $p<0,05$.

\section{HASIL}

Data (Tabel 1) menunjukkan sebagian besar sampel berusia kurang dati 40 tahun (42,9\%) dengan IMT pada kisaran normal $(37,2 \%)$ dan gambaran osteopenia $(42,1 \%)$, dan osteoporosis $(48,7 \%)$.

Tabel 1. Karakteristik subjek penelitian

\begin{tabular}{lr}
\hline \multicolumn{1}{c}{ Karakteristik } & \multicolumn{1}{c}{$\mathbf{N = 3 4 7}$} \\
\hline Usia & \\
$<40$ tahun & $149(42,9 \%)$ \\
$40-49$ tahun & $61(17,6 \%)$ \\
$50-59$ tahun & $79(22,8 \%)$ \\
60-69 tahun & $51(14,7 \%)$ \\
$>70$ tahun & $7(2,0 \%)$ \\
\hline
\end{tabular}


Tabel 1. Karakteristik subjek penelitian (Lanjutan)

\begin{tabular}{lr}
\hline \multicolumn{1}{c}{ Karrakteristik } & \multicolumn{1}{c}{$\mathbf{N}=\mathbf{3 4 7}$} \\
\hline IMT & \\
Berat badan kurang $(<18,5)$ & $24(6,9 \%)$ \\
Kisaran Normal $(18,5-22,9)$ & $129(37,2 \%)$ \\
Bobot badan lebih $(>=23,0)$ & $0(0,0 \%)$ \\
Berisiko(23,0-24,9) & $67(19,3 \%)$ \\
Obesitas $(<25,0)$ & $127(36,6 \%)$ \\
DMT & \\
Normal $(0-(+/-1,5)$ & \\
Osteopenia $\quad(+/-$ & $32(9,2 \%)$ \\
1,5)- $(+/-2,5)$ & $146(42,1 \%)$ \\
Osteoporosis $>(+/-$ & $169(48,7 \%)$ \\
2,5) & \\
\hline
\end{tabular}

Hubungan Faktor Risiko Osteoporosis Indeks Massa Tubuh dan Pemeriksaan Densitas Massa Tulang

Pada Tabel 2 tampak hal menarik bahwa pada kelompok obesitas (IMT >25) mempunyai proporsi osteopenia dan osteoporosis yang lebih besar demikiran juga pada kelompok dengan berat badan kurang $(<18,5)$. Proporsi pasien dengan osteoporosis ditemukan paling banyak pada mereka dengan berat badan kurang atau obesitas. Meskipun demikian, hasil uji chi square menunjukkan tidak ada hubungan antara pengelompokan IMT dan DMT.

Tabel 2. Perbandingan proporsi atau hubungan antara IMT dengan DMT

\begin{tabular}{lrrrr}
\hline \multirow{2}{*}{ IMT } & \multicolumn{3}{c}{ DMT } & \\
\cline { 2 - 4 } & $\begin{array}{c}\text { Normal } \\
\mathbf{N = 3 2}\end{array}$ & $\begin{array}{c}\text { Osteopenia } \\
\mathbf{N = 1 4 6}\end{array}$ & $\begin{array}{c}\text { Osteoporosis } \\
\mathbf{N = 1 6 9}\end{array}$ & Nilai P \\
\hline $\begin{array}{l}\text { Bobot badan kurang } \\
(<18,5)\end{array}$ & $4(12,5 \%)$ & $5(3,4 \%)$ & $15(8,9 \%)$ & 0,132 \\
$\begin{array}{l}\text { Kisaran Normal } \\
(18,5-22,9)\end{array}$ & $10(31,3 \%)$ & $51(34,9 \%)$ & $68(40,2 \%)$ & \\
$\begin{array}{l}\text { Bobot badan lebih } \\
(>=23,0)\end{array}$ & $0(0,0 \%)$ & $0(0,0 \%)$ & $0(0,0 \%)$ & \\
$\begin{array}{l}\text { Berisiko } \\
(23,0-24,9)\end{array}$ & $5(15,6 \%)$ & $36(24,7 \%)$ & $26(15,4 \%)$ & \\
$\begin{array}{l}\text { Obesitas } \\
(>25,0)\end{array}$ & $13(40,6 \%$ & $54(37,0 \%)$ & $60(35,5 \%)$ & \\
\hline
\end{tabular}

\section{DISKUSI}

\section{Karakteristik Sampel}

Usia merupakan salah satu faktor risiko terjadinya osteoporosis. Semakin bertambah usia maka akan terjadi peningkatan bone loss (kehilangan tulang), terutama pada lanjut usia. Pada penelitian ini diperoleh kebanyakan kelompok sampel pada wanita usia kurang dari 40 tahun, dimana nilai Indeks massa tubuh (IMT) terbanyak pada kelompok kisaran normal, yaitu angka IMT 18,5-22,9 dan obesitas (IMT>25). Terdapat temuan yang menarik yaitu responden berusia kurang 40 tahun dengan IMT kisaran normal namun terbanyak memiliki nilai DMT dalam kelompok osteoporosis. Hal ini dapat dijelaskan karena peningkatan kasus osteopenia terjadi pada usia muda. Depkes RI melalui kajiannya melaporkan bahwa kejadian osteopenia banyak ditemukan pada usia muda yang berumur kurang dari 25 tahun dengan prevalensi 37,1\% (12). Osteoporosis didahului dengan osteopenia yaitu suatu keadaan dengan kepadatan tulang rendah, yang berlangsung dalam jangka waktu lama sehingga mengakibatkan penurunan kekuatan tulang (12).

Wanita memiliki risiko enam kali lebih besar dibandingkan pria terkena osteoporosis dikarenakan massa tulang yang dimilikinya lebih sedikit dan lebih cepat mengalami kehilangan massa tulang. Teori menunjukkan bahwa pada usia diatas 40 tahun akan dimulai penurunan massa tulang dan akan terus berlanjut hingga kematian. Banyak teori yang menyatakan bahwa setelah menopause, akibat ketiadaan hormone estrogen mengakibatkan wanita kehilangan efek protektifnya, sehingga jalannya remodeling tulang terganggu dan akhirnya terjadi osteoporosis (13). Pada usia lanjut disamping terjadi penurunan massa tulang terdapat pula perubahan pada fungsi dan struktur otot. Massa otot akan menurun sejalan dengan pertambahan umur. Hal ini merupakan faktor prediktif yang penting dari keterbatasan fungsi dan disabilitas fisik pada usia lanjut serta tentunya meningkatkan risiko komplikasi fraktur/patah tulang (14).

Tingginya osteoporosis juga dipengaruhi perilaku dan gaya hidup yang tidak sesuai, termasuk didalamnya pengetahuan gizi, aktivitas olah raga dan memiliki kontrol atas kesehatannya. Salah satu faktor penting adalah asupan kalsium dianjurkan sebesar $500 \mathrm{mg} /$ hari untuk kelompok perempuan usia 29-49 tahun. Penelitian telah menunjukkan asupan kalsium yang rendah akan berpengaruh terhadap penurunan densitas tulang. Setyawati melaporkan bahwa hasil analisis statistik memperlihatkan konsumsi kalsium yang rendah berisiko dua kali lipat mengalami kepadatan tulang lebih rendah dibandingkan sampel dengan asupan kalsium cukup (15). Terdapat kecenderungan di Asia Timur dan Asia Tenggara, termasuk di Indonesia ditemukan tingkat asupan kalsium yang rendah dengan pola rendahnya asupan susu, terutama pada wanita $(9,15)$. Di samping asupan kalsium, hal yang penting juga adalah konsumsi fosfor, dan vitamin $D$ serta asupan protein. Protein berperan penting dalam pencapaian puncak massa tulang, sehingga individu dengan asupan protein rendah berisiko memiliki DMT yang rendah sehingga meningkatkan risiko kehilangan densitas massa tulangi (16). Disamping faktor nutrisi, aktivitas fisik juga berperan karena mengakibatkan gerakan mekanis yang memperkuat kekuatan tulangg sehingga dapat menentukan kesehatan tubuh. Densitas massa tulang dipengaruhi oleh aktifitas fisik dan olahraga yang bersifat pembebanan, tekanan/regangan otot dan gaya gravitasi $(9,17,18)$.

Hubungan Faktor Risiko Osteoporosis Indeks Massa Tubuh dan Pemeriksaan Densitas Massa Tulang

Indeks massa tubuh dapat menggambarkan status gizi seseorang. Indeks massa tubuh yang besar menyebabkan peningkatan beban mekanik tulang, produksi estrogen oleh jaringan adipose, sehingga menurunkan kecepatan pembongkaran massa tulang $(19,20)$. Penelitian Eka di Bandung menyimpulkan tidak ada hubungan antara IMT, massa lemak tubuh, dan lingkar pinggang dengan kepadatan tulang pada wanita dewasa awal (21). Moayyeri melaporkan bahwa prosentase lemak tubuh merupakan prediktor risiko patah tulang akibat osteoporosis pada wanita (19).

Pada penelitian ini tidak ditemukan hubungan bermakna diantara IMT dan DMT. Hal serupa juga ditemukan pada penelitian Setyawati, Mutia, dan Kementerian Kesehatan 
RI pada tahun 2007 bahwa tidak terdapat hubungan bermakna antara IMT dan DMT $(12,15)$. Namun beberapa penelitian lain menemukan hubungan bermakna antara IMT dan DMT, seperti yang dilakukan Farida di Pontianak (22). Penelitian Setyawati menunjukkan seseorang dengan postur tubuh kurus $(\mathrm{IMT}<18,5)$ berisiko osteoporosis sebesar 7 kali dibandingkan dengan yang memiliki postur tubuh normal (IMT $\geq 18,5$ (10). Massa otot memiliki peran penting pada DMT, terutama pada wanita premenopause dibandingkan pada wanita postmenopause. Meskipun demikian, keadaan genetik dan ras ikut mempengaruhi densitas massa tulang, massa lemak dan massa otot. Kim menemukan korelasi positif antara berat badan, IMT dan DMT pada tulang lumbal wanita dengan koefisien korelasi antara berat badan dan DMT lebih tinggi daripada antara IMT dan DMT, yang berarti bobot rendah jauh lebih mungkin berhubungan dengan osteoporosis tanpa faktor lain yang dipertimbangkan (23).

Hubungan tidak signifikan antara IMT dan DMT pada

\section{DAFTAR PUSTAKA}

1. Guido G, Scaglione M, Fabbri L, and Ceglia MJ. The "Osteoporosis Disease". Clinical Cases in Mineral and Bone Metabolism. 2009; 6(2): 114-116.

2. Szulc P and Bouxsein ML. Overview of Osteoporosis, Epidemiology and Clinical Management. Vertebrae Fracture Initiatiative. (Online) 2011. https://www.iofbonehealth.org/sites/default/files/ PDFs/Vertebral\%20Fracture\% 20Initiative/ IOF_VFIPart_I-Manuscript.pdf [diakses Maret 2018].

3. Varacallo MA and Fox EJ. Osteoporosis and Its Complications. The Medical Clinics of North America. 2014; 98(4): 817-831.

4. International Osteoporosis Foundation. Osteoporosis Facts and Statistics. (Online). https://www.iofbonehealth.org /facts-andstatistics/calcium-studies-map. [diakses tanggal 4 September 2018].

5. Kementerian Kesehatan Republik Indonesia. Data \& Kondisi Penyakit Osteoporosis di Indonesia. Jakarta: Kemenkes RI; 2015.

6. Cosman F, de Beur SJ, Leboff MS, et al. Clinician's Guide to Prevention and Treatment of Osteoporosis. Osteoporosis Internasional. 2014; 25(10): 23592381.

7. de Mesquita $\mathrm{AQ}$, Barbieri $\mathrm{G}$, and Barbieri $\mathrm{CH}$. Correlation between Ultrasound Velocity and Densitometry in Fresh and Demineralized Cortical Bone. Clinics (Sao Paulo). 2016; 71(11): 657-663.

8. Siris ES, Adler R, Bilezikian J, et al. The Clinical Diagnosis of Osteoporosis: A Position Statement from the National Bone Health Alliance Working Group. Osteoporosis International. 2014; 25(5): 1439-1443.

9. Setyawati B, Julianti ED, dan Adha D. Faktor yang Berhubungan dengan Densitas Mineral Tulang Perempuan Dewasa Muda di Kota Bogor. Penelitian Gizi dan Makanan. 2013; 36(2): 149-156.

10. Fawzy T, Muttappallymyalil J, Sreedharan J, et al. penelitian ini dapat disebabkan sampel yang diteliti memiliki IMT di kisaran IMT normal, sehingga data cenderung hampir sama dan rentangnya tidak terlalu lebar. Selain itu IMT saja tidak dapat menggambarkan secara pasti keadaan rangka sampel karena tidak dapat membedakan komposisi tubuh sampel apakah lebih didominasi massa lemak atau otot. Perbedaan hasil juga dapat disebabkan perbedaan alat ukur, dalam penelitian ini menggunakan metode QUS berbeda dengan Fawzy yang menggunakan alat ukur DEXA. Fawzy menemukan DMT rendah tercatat pada $59,1 \%$ perempuan dan $76,9 \%$ laki-laki. Hubungan antara usia lanjut dan BMI yang lebih rendah merupakan faktor risiko penting dalam terjadinya DMT rendah (10).

Hasil penelitian ini menyimpulkan bahwa pada sampel wanita di Kota Jambi, individu dengan obesitas menurut IMT cenderung mempunyai proporsi osteoporosis yang besar, meskipun secara statistik tidak ditemukan hubungan statistik bermakna diantara indeks massa tubuh dengan densitas massa tulang.

Association between Body Mass Index and Bone Mineral Density in Patients Referred for Dual-Energy $X$-Ray Absorptiometry Scan in Ajman, UAE. Journal of Osteoporosis. 2011; 2011: 1-4.

11. Pisani $P$, Renna MD, Conversano F, et al. Screening and Early Diagnosis of Osteoporosis through X-ray and Ultrasound Based Techniques. World Journal of Radiology. 2013; 5(11): 398-410.

12. Rahmani SM dan Probosari E. Hubungan Indikator Obesitas dengan Kepadatan Tulang pada Wanita Dewasa Awal. Journal of Nutrition College. 2016; 5(4): 444-451.

13. Ho SC, Chan SG, Yip YB, Chan CS, Woo JL, and Sham A. Change in Bone Mineral Density and Its Determinants in Pre-and Perimenopausal Chinese Women: The Hong Kong Perimenopausal Women Osteoporosis Study. Osteoporosis International. 2008; 19(12): 1785-1796.

14. Tantri N, Sunarti S, Nurlaila G, dan Wahono D. Sarcopenia, Exercise and Falls Incident at Elderly Population. Jurnal Kedokteran Brawijaya. 2014; 28(1):35-39.

15. Setyawati B, Prihatini S, Rohmah W, dan Pangastuti R. Hubungan Indeks Massa Tubuh dengan Densitas Mineral Tulang pada Perempuan Dewasa Muda. Penelitian Gizi dan Makanan. 2011;34(2): 93-103.

16. Pongchaiyakul C, Kosulwat V, Charoenkiatkul S, Chailurkit LO, Rojroongwasinkul N, and Rajatanavin R. The Association of Dietary Calcium, Bone Mineral Density and Biochemical Bone Turnover Markers in Rural Thai Women. Journal of the Medical Association of Thailand. 2008; 91(3): 295-302.

17. Iwamoto J, Sato Y, Takeda T, Matsumoto H. Role of Sport and Exercise in the Maintenance of Female Bone Health. Journal Bone Mineral and Metabolism. 2009; 27(5): 530-537.

18. Nugroho ISP dan Muniroh L. Hubungan Konsumsi Pangan Sumber Kalsium dan Aktivitas Fisik dengan Kepadatan Tulang Lacto Ovo Vegetarian di Yayasan 
Buddha Tzu Chi Surabaya. Media Glzi Indonesia. 2017; 12(1): 64-71.

19. Moayyeri A, Luben RN, Wareham NJ, and Khaw KT. Body Fat Mass is a Predictor of Risk of Osteoporotic Fractures in Women but not in Men: A Prospective Population Study. Journal of Internal Medicine. 2012; 271(5): 472-480.

20. Cao JJ. Effects of Obesity on Bone Metabolism. Journal of Orthopedic Surgery and Research. 2011; 6(1): 30-36.

21. Widyanti LRE, Kusumastuty I, dan Arfiani EP. Hubungan Komposisi Tubuh dengan Kepadatan
Tulang Wanita Usia Subur di Kota Bandung. Indonesian Journal of Human Nutrition. 2017; 4(1): 23-33.

22. Farida H. Hubungan Indeks Massa Tubuh dan Komposisi Tubuh dengan Densitas Massa Tulang Wanita Dewasa di Perwatusi Kota Pontianak. (Tesis). Ilmu Kesehatan Masyarakat UGM, Yogyakarta. 2012.

23. Kim SJ, Yang WG, Cho E, and Park EC. Relationship between Weight, Body Mass Index and Bone Mineral Density of Lumbar Spine in Women. Journal of Bone Metabolism. 2012; 19(2): 95-102. 